Markers of HTLV-III and risk factors for AIDS in five patients

\begin{tabular}{llccccc}
\hline Case & $\begin{array}{c}\text { Time of } \\
\text { seroconversion as } \\
\text { determined by } \\
\text { ELISA }\end{array}$ & $\begin{array}{c}\text { Viral proteins } \\
\text { shown by } \\
\text { Western blot }\end{array}$ & $\begin{array}{c}\text { Viral } \\
\text { antigens }\end{array}$ & $\begin{array}{c}\text { Period with } \\
\text { functioning kidney } \\
\text { transplant }\end{array}$ & $\begin{array}{c}\text { No of } \\
\text { transfusions }\end{array}$ & $\begin{array}{c}\text { Other risk } \\
\text { factors for AIDS }\end{array}$ \\
\hline 1 & January 1983 & & p15, p24 & June 1971-September 1980 & $>50$ \\
2 & June 1985 & p25 & p15, p24 & November 1977-July 1983 & $>50$ & From Zaire \\
3 & Not determined & p17, p24 & & $>20$ & Heterosexual \\
4 & October 1983 & p17, p25 & & & 8 & Hartner \\
5 & November 1984 & & & & with AIDS \\
\hline
\end{tabular}

ELISA = Enzyme linked immunosorbent assay

${ }^{\star}$ During five years before seroconversion as determined by ELISA.

infection with HTLV-III was found in five of 100 patients. In three patients positive on enzyme linked immunosorbent assay the presence of specific antibodies was confirmed by Western blot analysis, and HTLV-III antigens were found in the lymphocyte culture of one of them. Interestingly, lymphocyte cultures were found to be positive for HTLV-III antigens in two other patients in whom corresponding antibodies were detected only by enzyme linked immunosorbent assay. One patient presented with a clinical picture consistent with AIDS related complex, but the four other patients were asymptomatic.

In all five patients with evidence of HTLV-III infection immunity developed after 1982. This finding is consistent with the current knowledge of the epidemiology of AIDS, and similar data have been reported in haemophiliacs. ${ }^{4}$

The putative source of HTLV-III was unrelated to haemodialysis in two patients, whereas blood transfusion was the most likely mode of contamination in the others. The lack of seropositivity among our staff members confirms that the risk of nosocomial infection with
HTLV-III is low when precautions similar to those recommended $\frac{\frac{5}{\bar{T}}}{\frac{\widehat{T}}{2}}$ for the control of hepatitis B infection are applied.

We thank the nurses of the dialysis unit for their efficient collaboration and Mrs Sonia Najdovski for her help in preparing the manuscript. This work $\vec{\circ}$ was supported by the Fonds National Belge de la Recherche Scientifique (grant number 3.4517.84).

\section{References}

1 Feorino PM, Jaffe HW, Palmer E, et al. Transfusion-associated acquired immunodeficiency syndrome. N Engl f Med 1985;312:1293-6.

Thiry L, Sprecher-Goldberger S, Jacquemin P, et al. Bovine leukemia virus-related antigens in lymphocyte cultures infected with AIDS-associated viruses. Science 1984;227:1482-4.

Neumayer $\mathrm{HH}$, Wagner $\mathrm{K}$, Kresse S. HTLV-III antibodies in patients with kidney transplants or on haemodialysis. Lancet 1986;i:497.

Eyster ME, Goedert JE, Sarngadharan MG, et al. Development and early natural history of $N$ HTLV-III antibodies in persons with hemophilia fAMA 1985;253:2219-23.

5 Favero MS. Recommended precautions for patients undergoing hemodialysis who have AIDS or non-A, non-B hepatitis. Infect Control 1985;6:301-5.

(Accepted 16 April 1986)

\title{
Cytomegalovirus but not human T lymphotropic virus type III/ lymphadenopathy associated virus detected by in situ hybridisation in retinal lesions in patients with the acquired immune deficiency syndrome
}

\author{
PETER G E KENNEDY, DAVID A NEWSOME, JAY HESS, OPENDRA NARAYAN, \\ DONNA L SURESCH, W RICHARD GREEN, ROBERT C GALLO, B FRANK POLK
}

\author{
Abstract \\ Paraffin sections of retinal tissue from five patients who died from \\ the acquired immune deficiency syndrome (AIDS) and retin-

\footnotetext{
Departments of Neurology, Comparative Medicine, and Epidemiology and Wilmer Eye Institute, Johns Hopkins Medical Institution, Baltimore, Maryland 21205, United States

PETER G E KENNEDY, MD, MRCP, visiting assistant professor of neurology DAVID A NEWSOME, MD, associate professor of ophthalmology

JAY HESS, BA, fellow of the Medical Scientist Training Programme, department of neurology

OPENDRA NARAYAN, DVM, PHD, professor of neurology and comparative medicine

DONNA L SURESCH, HTASCP, research technician, department of neurology W RICHARD GREEN, MD, professor of ophthalmology

B FRANK POLK, MD, professor of epidemiology

Laboratory of Tumor Cell Biology, National Cancer Institute, National Institutes of Health, Bethesda, Maryland 20205, United States

R C GALLO, MD, chief

Correspondence to: Professor Narayan.
}

opathy were examined by in situ hybridisation experiments with $ᄋ$ deoxyribonucleic acid (DNA) labelled with sulphur-35 of lenti- N virus, human T lymphotropic virus type III/lymphadenopathy associated virus (HTLV-III/LAV), and cytomegalovirus. HTLVIII/LAV ribonucleic acid (RNA) was not detected in any of the tissue sections. Cytomegalovirus RNA was identified, however, in three of the five patients.

Retinopathy induced by cytomegalovirus may thus be one of the many syndromes potentiated by the immunosuppression caused by HTLV-III/LAV.

\section{Introduction}

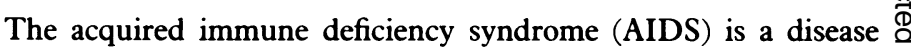
characterised by the selective loss of helper $\mathrm{T}$ lymphocytes, resulting in severe impairment of immune mechanisms ${ }^{12}$ and is $O$ thought to be caused by infection of the cells with human $T \frac{0}{0}$ lymphotropic virus type III/lymphadenopathy associated virus (HTLV-III/LAV). ${ }^{34}$ HTLV-III/LAV is also thought to cross the 
blood brain barrier and produce compromised central nervous system function in a large percentage of patients with AIDS. Various AIDS related diseases, especially opportunistic infections, have been described, including an unusually high incidence of retinopathy. ${ }^{56}$ Whether the retinopathy is caused by HTLVIII/LAV or another opportunistic agent such as cytomegalovirus has not been established unequivocally. We therefore used in situ molecular hybridisation with cloned radiolabelled HTLV-III and cytomegalovirus deoxynucleic acid (DNA) probes to examine affected eyes for the presence of these agents.

\section{Patients and methods}

Human tissue-The eyes from five men aged 20-59, who had died from AIDS were removed at necropsy and fixed in formaldehyde. All the patients fulfilled the criteria for AIDS as defined by the Centers for Disease Control, had severe retinopathy during their illness, and had antibodies to HTLVIII/LAV. Paraffin sections $(10 \mu \mathrm{m})$ of the whole eyes were cut and placed on to glass slides coated with polylysine for in situ hybridisation studies. Some sections of each eye were stained only with haematoxylin and eosin. All sections were coded before in situ hybridisation studies

In situ hybridisation-This was carried out as previously described. ${ }^{8}$ Briefly, the tissue sections were pretreated with acid, heat, proteinase $\mathrm{K}$, and acetylation. Cloned HTLV-III DNA was separated from the plasmid vector pSP64 by digestion with SstI, and the resulting $8.9 \mathrm{~Kb}$ viral DNA fragment was purified by electrophoresis in agarose gels. Cloned cytomegalovirus DNA was obtained from Bethesda Research Laboratories. The DNA of both viruses was labelled by nick translation with deoxyadenesinetric phosphate labelled with sulphur-35 and deoxycytosinetric phosphate labelled with sulphur-35 (Amersham, Arlington Heights, Illinois), ${ }^{8}$ and fragments measuring an average of $70-110$ base pairs were used. The specific activities of the probes were greater than $3 \times 10^{8} \mathrm{cpm} / \mu \mathrm{g}$. Similarly prepared probes of visna virus, which has some genetic homology to HTLV-III," can detect between one and 10 copies of viral ribonucleic acid(RNA)/grain. ${ }^{10}$ The radiolabelled DNA probes (HTLV-III and cytomegalovirus) were reacted with the eye sections at a concentration of $0 \cdot 2 \mathrm{ng} / \mu \mathrm{l}$ for 48 hours, after which the slides were washed thoroughly ${ }^{8}$ and autoradiographed for five to 10 days. Viral RNA was identified by silver grains over the cells. To control for the specificity both probes were applied to paraffin sections of spleen tissue obtained from a patient dying from AIDS and also to normal spleen sections of a subject who did not have AIDS. After autoradiography all sections were then stained with haemotoxylin and eosin.

\section{Results}

Clinical appearance and histological changes-Table I gives the clinical, gross pathological, and microscopic retinal findings in each of the five patients. The clinical diagnosis of cytomegalovirus retinitis was made in two patients (cases 4 and 5) on the basis of a characteristic whitish retinal infiltrate with retinal and retinovascular necrosis and haemorrhage without overlying vitreous disease. The duration of cytomegalovirus retinitis before necropsy was between four and five months in either case. Examination of the retinal sections of these two clinically diagnosed cases of cytomegalovirus showed focal dystrophic changes with severe loss of neurones and disorganisation of the retinal architecture. In addition, many mononuclear and some polymorphonuclear cells had infiltrated these areas, particularly around vessels and the less necrotic borders. Several of the retinal neurones and some of the inflammatory cells had large intranuclear eosinophilic and periodic acid Schiff positive inclusion bodies suggestive of cytomegalovirus infection. One patient's eyes (case 5) also showed inclusion bodies in retinal pigment epithelial cells. Other areas of the retina appeared normal.

In situ hybridisation-Hybridisation experiments showed that cytomegalovirus RNA was present in the retinas of the two patients with clinically diagnosed cytomegalovirus retinitis and also in much smaller amounts in a few cells in the retina of another patient (case 3). Cytomegalovirus RNA was found in many of the cells in the areas with severe lesions (fig 1) and was present in neurones of both the ganglionic and plexiform layers and some of the inflammatory cells. Many of the cells bearing eosinophilic intranuclear inclusion bodies, pathognomonic of cytomegalovirus infection, did not contain cytomegalovirus RNA. No hybridisation was seen in areas of the retinas that appeared normal. The HTLV-III probe did not hybridise to cells in any of the sections (fig 2), including the retinas and corneal surfaces. To make sure that this was not a technical artefact we performed hybridisation with this probe on sections of spleen from a patient with AIDS. A small number of cells bearing 50-100 grains were identified scattered throughout the splenic parenchyma (fig 3). The cytomegalovirus probe did not hybridise to these tissue cells. Neither probe hybridised to cells in tissue sections of normal spleen.

\section{Discussion}

Retinopathy has recently been recognised as a major complication of AIDS, " but it is not clear whether the pathological changes are caused by replication of the HTLV-III/LAV within retinal cells or whether the lesions are caused by another infective agent, possibly potentiated by HTLV-III/LAV. The histological identification of

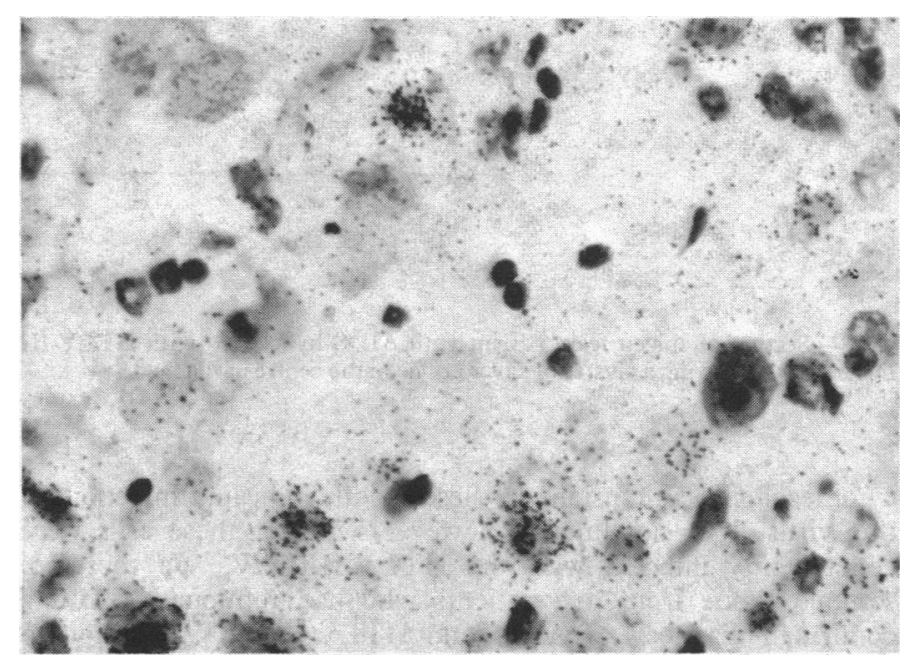

FIG 1-Formaldehyde fixed paraffin embedded section of retina from patien (case 5) with retinitis and AIDS hybridised with ${ }^{35} \mathrm{~S}$ radiolabelled cytomegalo virus DNA probe. Several cells contain viral RNA, shown by silver grains. Cells with inclusion bodies are also seen.

\begin{tabular}{|c|c|c|c|c|}
\hline $\begin{array}{l}\text { Case } \\
\text { No }\end{array}$ & $\begin{array}{c}\text { Age } \\
\text { (years) }\end{array}$ & Clinical appearance & Gross findings & Microscopic findings \\
\hline 1 & 40 & Few posterior pole cotton wool spots in both eyes & Inner retinal cytoid bodies in both eyes & $\begin{array}{l}\text { Mild papilloedema } \\
\text { Retinal microintarcts in both eyes }\end{array}$ \\
\hline 2 & 20 & $\begin{array}{l}\text { White, fluffy solid lesions in superficial retina and } \\
\text { vitreous; Rothtype spots in both eyes }\end{array}$ & $\begin{array}{l}\text { White, fluffy lesions close to posterior pole vessels in } \\
\text { both eyes }\end{array}$ & $\begin{array}{l}\text { Candidiasis of retina and vitreous in both eyes } \\
\text { Retinal microinfarcts in both eyes }\end{array}$ \\
\hline 3 & 32 & Cotton wool spots in both eyes & Inner retinal cytoid bodies in both eyes & $\begin{array}{l}\text { Retinal vasculitis (polymorphonuclear neutrophilic and } \\
\text { mononuclear), local necrosis in both eyes } \\
\text { Mild papilloedema } \\
\text { Retinal microinfarcts in both eyes }\end{array}$ \\
\hline 4 & 59 & $\begin{array}{l}\text { Whitish area of retinitis with vasculitis and retinal } \\
\text { haemorrhage posterior pole, cotton wool spots, } \\
\text { minimal vitreous cells in both eyes }\end{array}$ & $\begin{array}{l}\text { Acute appearing retinochoroiditis, predominantly in } \\
\text { posterior poles in both eyes }\end{array}$ & $\begin{array}{l}\text { Retinal necrosis, vasculitis, choroiditis in both eyes } \\
\text { Large cells in retinas with viral inclusions in both eyes }\end{array}$ \\
\hline 5 & 42 & $\begin{array}{l}\text { Focal spreading whitish areas of retinal necrosis, cotton } \\
\text { wool spots, minimal yitreous cells in both eyes }\end{array}$ & $\begin{array}{l}\text { Retinochoroiditis and vasculitis, predominately } \\
\text { posterior pole in both eyes }\end{array}$ & $\begin{array}{l}\text { Retinal necrosis, vasculitis, choroiditis in both eyes } \\
\text { In addition to cells in retina, retinal pigment epithelial } \\
\text { cells showed viral inclusions }\end{array}$ \\
\hline
\end{tabular}




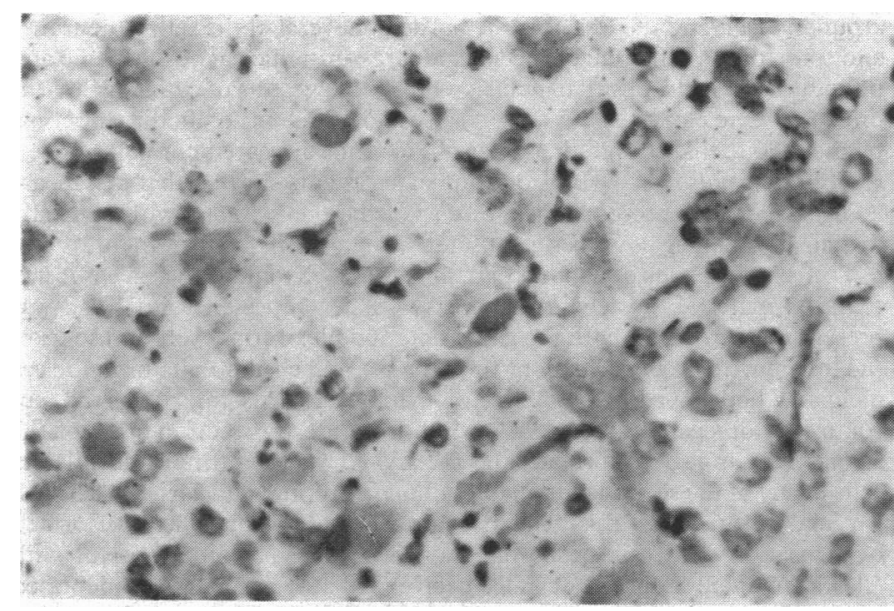

FIG 2-Formaldehyde fixed paraffin embedded section of retina from patient (case 5) with retinitis and AIDS unlabelled with the HTLV-III probe.

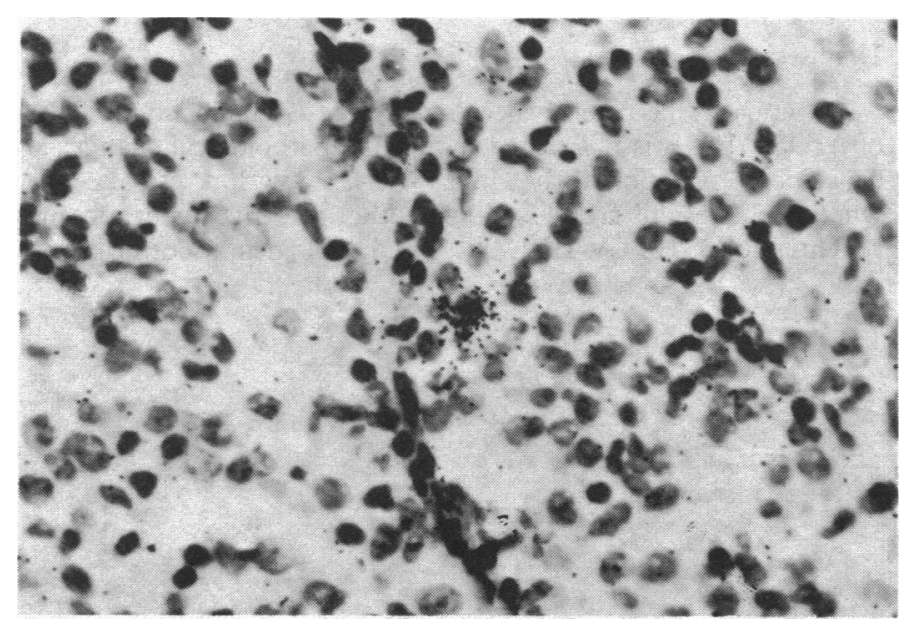

FIG 3-Section of spleen from patient with AIDS hybridised with HTLV-III DNA probe, showing a cluster of silver grains in the centre of the field.

cytomegalovirus inclusions in these lesions indicated infection by this virus. It is not known, however, whether these cells were concurrently infected with the HTLV-III/LAV. We therefore selected tissue from five patients who had retinopathy with a confirmed diagnosis of AIDS and HTLV-III/LAV infection to perform hybridisation using probes of both viruses. Surprisingly, HTLV-III was not detected in any of the patients studied, but extensive replication of cytomegalovirus was detected in three out of the five patients, suggesting that cytomegalovirus may have caused the lesion in these patients. The lack of cytomegalovirus RNA in some cells with intranuclear inclusions is interesting and may reflect different stages of replication of this virus. HTLV-III may have been present in such low copy numbers in the retinal lesions that our in situ hybridisation technique was not sensitive enough to detect it. This is unlikely, although previously probes made with lentivirus DNA have detected one to 10 copies of viral genomes in each cell. ${ }^{10} 12$

Although HTLV-III has recently been identified in the tears of one patient with AIDS, ${ }^{13}$ the incidence of HTLV-III/LAV in the tears of such patients is unknown, and this may be a rare event. Our data suggest that at the particular stage of the disease studied in our five patients there was no evidence of HTLV-III in their retinas. This observation, coupled with proved systemic infection with cytomegalovirus in all of these patients with AIDS and retinopathy, suggests that cytomegalovirus is a more likely agent than HTLVIII/LAV in the production of focal retinal vascular, inner retinal disturbances (clinically known as cotton wool spots) seen in most patients with AIDS. Our data do not, however, provide any direct information on the actual aetiological agent or agents that produce cotton wool spots. In fact one patient (case 1) had a few cotton wool spots but was negative for retinal cytomegalovirus. All three of our patients who were positive for cytomegalovirus showed evidence of retinal vasculitis and some necrosis, typical histopathological features of cytomegalovirus retinitis. None of our patients received $\stackrel{\varrho}{\complement}$ the antiviral dihydroxypropoxy methyl guanine (DHPG), currently being studied for efficacy in a cooperative clinical trial in the United States. The effects of this agent on the numbers of cotton wool spots would be interesting. Whether HTLV-III/LAV is present at an earlier stage of the ophthalmic disease is not known and should bem investigated in further studies.

This work was supported in part by grants NS21916, NS12127, and $\overrightarrow{\overline{\vec{N}}}$ SMO1RR-00722 from the National Institutes of Health and grants from the Charles A Dana Foundation, the King's Fund, London, and the Wellcome Trust. We thank Drs Tom Moench and Richard Johnson for helpful advice and Linda Kelly for typing the manuscript.

\section{References}

1 Lane HC, Masur H, Edgar LC, Whalen G, Rook AH, Fauci AS. Abnormalities of B-cell activation and immunoregulation in patients with the acquired immunodeficiency syndrome. $N \vec{\omega}$ Engl f Med 1983;309:453-8.

2 Stahl RE, Friedman-Kien A, Dubin R, Marmor M, Zolla-Pazner S. Immunologic abnormalities음 in homosexual men: relationship to Kaposi's sarcoma. Am J Med 1982;73:171-8.

3 Popovic M, Sarngadharan MG, Read E, Gallo RC. Detection, isolation and continuousi production of cytopathic human T lymphotropic retrovirus (HTLV-III) from patients with

4 Barre-Sinoussi F, Chermann J, Rey F, et al. Isolation of a T-lymphotrophic retrovirus from a patient at risk for acquired immune deficiency syndrome (AIDS). Science 1983;220:868-71. Curran JW, Morgan WM, Hardy AM, Jaffe HW, Darrow WW, Dowdle WR. The epidemiology?

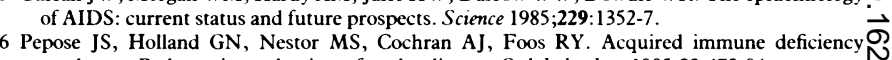
syndrome. Pathogenic mechanism of ocular disease. Ophthalmology 1985;92:472-84.

Fauci AS, Macher AM, Longo DE, et al. Acquired immunodeficiency syndrome: epidemiological, clinical, immunologic and therapeutic considerations. Ann Intern Med 1984;100:92-106.

8 Gondelman HE, Moench TR, Narayan O, Griffin DE, Clements JE. A double-labelling technique $\vec{\theta}$ for performing simultaneous immunocytochemistry and in situ hybridization in virus infectede cell cultures and tissues. $\mathcal{F}$ Virol Meth 1985;11:93-103.

9 Gonda MA, Wong-Staal F, Gallo RC, Clements JC, Narayan O, Gilden RV. Sequence homology and morphologic similarity of HTLV-III and visna virus, a pathogenic lentivirus. Science $\vec{c}$ 1985;227:173-7.

10 Gendelman HE, Narayan O, Molineaux S, Clements JE, Ghotbi Z. Slow persistent infection of lentiviruses: role of macrophages and macrophage-precursors in bone marrow. Proc Natl Acad Sci $1985 ; 82: 7086-90$.

11 Newsome DA, Green WR, Miller ED, et al. Microvascular aspects of acquired immunodeficiency syndrome retinopathy. Am $\mathcal{F}$ Ophthalmol 1984;98:590-601.

12 Haase AT, Stowring L, Harris JD, et al. Visna DNA synthesis and the tempo of infection in vitro.

Virology 1982;119:399-410.
13 Fujikawa LS, Salahuddin SZ, Palestine AG, Masur H, Nussenblatt RB, Gallo RC. Isolation of human T-lymphotropic virus type III from the tears of a patient with the acquired immunodeficiency syndrome. Lancet 1985; ii:529-30.

(Accepled 28 April 1986)

(A)

\section{YEARS AGO}

A correspondent writes to us: It is time to utter a protest against a proceeding which has assumed proportions which render it positively dangerous to contribute a readable article to a medical journal bearing on any new or promising method of treatment. We allude to the practice which has grown up, on the part of provincial practitioners more particularly, of writing to the author of the article with a series of questions, often irrelevant or already answered, but overlooked by the very men who so unscrupulously trespasso on their senior's time and patience. For example, the writer of a recentw contribution on a new remedy assured us that he had received upwards of 200 letters during the first four days following the publication of his remarks Few of the inquirers thought it desirable to prepay the answer; and, it may be added, fewer still ever acknowledged or thanked him for his reply. Many ofs the applicants went so far as to describe the symptoms of a particular case, and discuss the appropriateness of this or that remedy, and so obtain the benefit of a consultation gratuitously. Such letters can scarcely be left without a reply, for that would offend the writers wholesale; and it is difficulin to see how any observation on the subject could be couched so as to avoida hurting their feelings. The practice is, nevertheless, a dubious one, and ito ought to be understood that, in soliciting information on a subject of which the writer of the article may have made a special study, probably at no smale expense to himself in money, time, and trouble, it is only reasonable that he should receive some remuneration, and that without the necessity of asking for it. (British Medical Fournal 1886;i:32.) 